Article

\title{
Double Burden of Disability and Poverty: Does Vocational Rehabilitation Ease the School-to-Work Transition?
}

\author{
Nancy Reims ${ }^{1, *}$ and Silke Tophoven ${ }^{2}$ \\ ${ }^{1}$ Joblessness and Social Inclusion Research Department, Institute for Employment Research (IAB), Germany; \\ E-Mail: nancy.reims@iab.de \\ ${ }^{2}$ Faculty of Social Sciences and Cultural Studies, University of Applied Sciences Duesseldorf, Germany; \\ E-Mail: silke.tophoven@hs-duesseldorf.de \\ * Corresponding author
}

Submitted: 1 July 2021 | Accepted: 13 September 2021 | Published: 13 October 2021

\begin{abstract}
Poor young people more often face health difficulties, (learning) disabilities, and are overrepresented in special schools. Consequently, youth from poor households disproportionately frequently participate in disability-specific programs aiming to improve their educational levels and labor market opportunities. They face a double burden of disability and poverty. In our study, we look at poor and non-poor youth with disabilities (YPWD) who participate in vocational rehabilitation (VR) and whether VR helps them (a) in transitioning into employment and (b) in leaving poverty. We examine the association between the receipt of initial basic income support (BIS) as a poverty indicator, later labor market outcomes, and earned vocational qualification using administrative data. We make use of a sample of all persons accepted for VR in 2010 $(\mathrm{N}=36,645)$. We employ logit models on VR attendees' labor market outcomes three and five years after being accepted for VR as well as on their earned vocational qualifications. Beside initial poverty status, we control for educational level, type, and degree of disability and program pattern during the VR process. Our findings show that YPWD from poor households have a decreased likelihood of a vocational certificate and employment. Additionally, they are more likely to receive BIS than young people not from poor households and thus more likely to remain poor. In conclusion, VR seems to support poor YPWD less in their school-to-work transitions. Thus, disability-specific programs should be more tailored to the social situations of participants, and counsellors should be more sensitive to their social backgrounds.
\end{abstract}

\section{Keywords}

basic income support; Germany; labor market integration; school-to-work transition; vocational rehabilitation; youth

\section{Issue}

This article is part of the issue "Promoting Inclusion and Equality in Education" edited Allen Thurston (Queen's University Belfast, UK) and Tien-Hui Chiang (Anhui Normal University, China).

(C) 2021 by the authors; licensee Cogitatio (Lisbon, Portugal). This article is licensed under a Creative Commons Attribution 4.0 International License (CC BY).

\section{Introduction}

In Germany, $14 \%$ of all children under the age of 18 grow up in poor households. Forty percent of poor young people under the age of 25 live for four years or more in poverty households (Statistik der Bundesagentur für Arbeit, 2021a, 2021c). Growing up in poverty can have several negative consequences in different spheres of life, e.g., lower educational opportunities or higher risks for disabilities (particularly learning disabilities; see, e.g., Brooks-Gunn \& Duncan, 1997). In addition, poor children have a higher risk of poverty later in life (Groh-Samberg \& Voges, 2014). Protective factors against poverty include education (Brooks-Gunn \& Duncan, 1997) and employment (Groh-Samberg \& Voges, 2014). Therefore, first labor market experiences are meaningful for subsequent employment biography (Schmillen \& Umkehrer, 2017). This applies particularly to disadvantaged youth such 
as those with disabilities and those from poor families (Osgood et al., 2005). Thus, the school-to-work transition (STWT) for those with disabilities from low-income families is twice as challenging (Enayati \& Karpur, 2018). This is particularly relevant, as studies on the STWT often neglect persons with disabilities as a group. However, based on statistical documentation, we know that in 2020 in Germany, 34,576 young people with disabilities (YPWD) started vocational rehabilitation (VR) to support their STWT. The yearly number of young people in VR is approximately 130,000 . Among those, the relatively high proportion of young adults living in (parental) households receiving basic income support (BIS; 23\% in 2020) is striking (Statistik der Bundesagentur für Arbeit, 2021b).

The link between poverty and disability in the labor market transition has not yet been systematically addressed in the context of VR. Therefore, we stress the intersection of poverty and disability and shed light on a group of young people starting their STWT with the double burden of poverty and disability. Against this background, we examine whether VR supports youth initially receiving BIS in their own or their parents' household (a) in transitioning into employment and (b) in leaving poverty.

\section{Social-Legal Background for VR and Previous Research}

\subsection{Vocational Rehabilitation as Support for the School-to-Work Transition Among Youth With Disabilities}

Various social policy programs in Germany focus on disadvantaged youth and their labor market integration (Achatz et al., 2020). VR, according to Social Code IX, focuses on YPWD, aiming to improve their labor market chances while providing programs with disabilityspecific support (e.g., psychological, sociopedagogical). Therefore, VR has been an important instrument to achieve the full labor market integration and social inclusion of YPWD according to the UN Convention on the Rights of Persons with Disabilities of 2008 (Shakespeare et al., 2018). In Germany, YPWD in their STWT access VR through local employment agencies and job centers; clinics, doctors and psychiatrists, as well as schools, also function as important gatekeepers. Aiming to support the STWT of YPWD, VR is mainly financed by the Federal Employment Agency (FEA) and implemented by VR departments in local employment agencies. A precondition for receiving VR is having a disability according to Social Code III, which defines eligible individuals as "individuals whose prospects of participating or continuing to participate in working life are substantially impaired, other than temporarily... and who consequently need help to promote their labor market participation, including persons with learning disabilities" (Federal Ministry of Labour and Social Affairs, 2020, p. 36).

\subsection{Previous Research}

YPWD participating in VR are very heterogeneous. Approximately half of the participants have learning disabilities; in addition, a large and increasing proportion have psychological disabilities, and a smaller proportion have physical, mental and sensory disabilities (Reims et al., 2018). Qualitative results show that many YPWD face multiple disabilities (Tisch et al., 2017) that call for specific requirements in VR (Tophoven et al., 2019). Furthermore, different individuals with the same disability may differ significantly in the extent of limitations and manifestations of disability. This heterogeneity makes it necessary for YPWD to receive tailored and individual support during VR. There are a broad range of VR programs, including technical assistance, individual coaching, psychological counseling, sheltered workshops, and prevocational and vocational training programs. Most vocational training programs within VR take place in vocational institutions at specific service providers with different shares of in-company phases (71\%), but vocational training can also be performed as (subsidized) in-company training (29\%; Reims et al., 2018). Previous results found that approximately half of YPWD participated in vocational training and about two third of them completing VR are employed (Reims \& Gruber, 2014; Tophoven et al., 2019).

Almost one-third of YPWD in VR are former special school students (Reims et al., 2018). Seventy-two percent of the graduates of special schools did not receive a general education certificate (KMK, 2020). The lack of certification leads to poorer opportunities in the training and labor market (Gebhardt et al., 2011; Niehaus et al., 2012; Pfahl \& Powell, 2011). Thus, for many YPWD in VR, obtaining general school qualifications and vocational training perspectives is crucial (Reims \& Gruber, 2014). In 2011, in Germany, a recommendation on the inclusive education of children and YPWD in schools was adopted, referring to the UN Convention on the Rights of Persons with Disabilities of 2008 (KMK, 2011). Since then, the number of students at special schools has decreased slightly, but at the same time, the number of students with special educational needs has increased. However, in $2018,58 \%$ of students with special educational needs attended special schools. Most of them were assigned to a special focus on learning (35\%). Previous findings show that children in special schools with a focus on learning often come from families with low material resources (Heimlich, 2017) and that students with special education learning needs are often affected by poverty later in life (Rosenberger, 2017). Additionally, children from low-income households have a higher risk for worse general and mental health (Lampert \& Kuntz, 2019). Furthermore, having children with disabilities is a possible poverty risk for families (Vinck \& Van Lancker, 2019). In Germany, the intergenerational transmission of poverty and life-course risks has been shown (Groh-Samberg \& Voges, 2014). Several programs focus 
on the STWT, but they do not seem to be tailored to the individual circumstances and aspirations of all young people. This is true especially for young people leaving school without qualifications and those from families on long-term BIS (Achatz et al., 2020). In addition, in Germany, the segregated school and vocational education system perpetuates differences based on social origin (Protsch \& Solga, 2016). These studies do not particularly consider YPWD.

Enayati and Karpur (2018) examine how participation in social policy programs with a focus on the STWT can generally support YPWD from welfare-receiving households. They find that participation leads to higher employment rates and lower criminal behavior but also to lower wages. In Germany, however, there is little evidence on the specific situation of YPWD in VR in terms of achieving successful labor market integration and overcoming the need for BIS. With regard to the relationship between poverty and participation in VR, a first comparison based on the regular reporting of the statistics of the FEA (Statistik der Bundesagentur für Arbeit, 2021b) already shows some differences. Labor market prospects were found to be worse for YPWD in VR who were receiving BIS than for those who were not receiving BIS. Twelve months after completing VR, $72 \%$ of those not receiving BIS were employed, and nine percent were registered unemployed; among those with the initial receipt of BIS, only $42 \%$ were employed, whereas $27 \%$ were registered unemployed. These findings motivate us to particularly investigate poor YPWD in VR. Therefore, we focus on YPWD with and without initial BIS, either in their parents' or their own households, as poverty indicator and apply multivariate analyses to look at their labor market outcomes, vocational qualifications and poverty situations three and five years after starting VR in 2010.

\section{Theoretical Considerations}

Social policy aims at societal inclusion and participation of all members of a society regardless of their ethnic origin, religion, age, disabilities, gender, and sexual orientation (Bäcker et al., 2020). Social origin can be added here. Inclusion refers to the participation of all members of a society in the political process, in the access to resources, but also in the opportunities to increase and shape these resources. Inclusion should target the socially excluded (e.g., people with disabilities and poor people) and link the existing debates (Boeckh et al., 2017, p. 138). From a human rights perspective, there is a clear framework for inclusion and participation of persons with disabilities established in the UN Convention on the Rights of Persons with Disabilities. This also results in the demand for an inclusive educational system (article 24). In Germany, there is still a need for reforms, as the right to inclusive education is in conflict with the deeply rooted segregated school and special school system (Blanck et al., 2013; Klemm, 2021). In addition, since education policy in Germany is a matter for the 16 fed- eral states, appropriate implementation must take place in all 16 states. Furthermore, there are still many blind spots regarding transitions of people with disabilities to vocational education and training and the implementation of inclusion in these areas, and thus ultimately for labor market entry and opportunities (Federal Ministry of Labour and Social Affairs, 2021).

Thereby education and labor market participation are key elements for sustainable inclusion and participation. However, educational and labor market opportunities are not equally distributed. In Germany, the social background plays a key role in mediating these differences. The different resources available at home are related to educational inequalities and decisions (Becker \& Lauterbach, 2016). This is again reinforced by the segregated German school system, which focuses on homogenization of performance at an early stage (Protsch \& Solga, 2016). In poor households, there is an undersupply of economic resources, which is often related to an undersupply in other areas like health and educational opportunities as mentioned above (e.g., Brooks-Gunn \& Duncan, 1997; Heimlich, 2017; Lampert \& Kuntz, 2019). The STWT is classified as a sensitive (Blossfeld, 1988) and critical (Marshall \& Mueller, 2003) shift in status in all individuals' life courses. In transition processes like the STWT, existing social inequalities are seen to be further reinforced (Rosenberger, 2017). The paths chosen and subsequent successes and struggles determine further labor market success and are related to individual life opportunities. Compared to those with better starting conditions, for vulnerable youth, this transition process can be like "a minefield" (Osgood et al., 2005, p. 2). Moreover, Pisoni (2018, p. 289) describes a possible Matthew effect within social policy programs for vulnerable youth: "The least-disadvantaged individuals among a targeted group are more able to benefit from social policy schemes than their more-disadvantaged counterparts."

Shifting these perspectives to poor YPWD participating in VR, their accumulating challenges in the process of labor market integration become clear and may even intensify over time or during critical transitions. Poor YPWD have to cope with their health, develop their career prospects and catch up on qualifications with limited financial, educational and social resources. Thus, they must be assumed to have a higher level of vulnerability than those in more financially secure conditions. Therefore, for poor YPWD, we assume a smaller benefit from participation in VR regarding labor market integration and a risk of continuing to rely on BIS and therefore remain poor.

\section{Data and Methods}

For our analyses, we used the Reha-Process Data Panel (RehaPro). This data set is based on administrative data from the FEA and the only representative data set for young VR participants (Reims et al., 2018). The observa- 
tion period for VR information ranges from June 2006 to April 2016. The data include (disability-specific) information on all VR applicants financed by the FEA within this period. Variables on daily information on the VR process, participation in active labor market programs (ALMP) and vocational training, and periods of (un)employment before and after VR are included, as well as the previous school biography. We restricted the data to those individuals accepted for VR in 2010 and individuals with information for the variable initial receipt of BIS in the household/role of recipient (exclusion of 1,272 cases). Furthermore, we excluded those with mental disabilities ( $n=7,270$ ) from the sample, as we observed unplausible effects, possibly because persons with mental disabilities automatically transfer from sheltered training during VR to sheltered employment. Our final sample contained 36,645 individuals.

As a poverty measure among the VR participants, we observed initial receipt of BIS in the household/role of recipient as the central independent variable. According to Social Code II, BIS provides means-tested minimum income benefits for those below the defined subsistence level (Nullmeier, 2018). BIS is granted at the household level. The amount of support considers the existing income of all employable household members. BIS, as financial assistance, can also be paid in addition to (employment) income. Receiving BIS results in an income that is very close to the income poverty line for all household members and is therefore a poverty indicator (Munz-König, 2013). This variable described whether YPWD were part of a household receiving BIS and their role within the household at the beginning of VR, thus, whether they lived on their own or together with their parents. As further dimensions of SES, we include schooling certificate and the requirement level of the aspired occupation within vocational training programs in VR. This variable ranged from unskilled or semiskilled activities to specialist activities (at least two years of vocational training) to complex specialist activities (qualification as master craftsman or technician, graduation from a professional academy or university bachelor's certificate) to highly complex activities (completed university studies of four years; see Paulus \& Matthes, 2013). However, as not all YPWD take part in vocational training during VR, we observed this information for $58 \%$ of the population.

Furthermore, by observing the whole VR process, we generated a variable for type of main program pattern in $V R$ as we often observed participation in different programs (the mean was approximately 2.3 programs). Thus, we considered that typical program combinations exist (Reims et al., 2018). Additionally, we used different sociodemographic information such as gender, age, and further disability characteristics: status and type of disability. The type of disability did not indicate multiple diagnoses but rather the disability that was mainly responsible for the individual receiving VR. Another variable that we only used for the sample description was reasons for ending $V R$. This information is recorded at the end of the VR process by the VR counsellor and does not include information on receipt of BIS.

To observe the labor market transition of YPWD after $V R$, we defined five outcome categories for three and five years after the beginning of VR in 2010: "basic income receipt," "employment," "sheltered employment," "still/again in VR" and "no information." The latter category could indicate, e.g., periods of economic inactivity, periods of child rearing or vocational training at full-time schools. As some outcome statuses could exist simultaneously at the measured point in time, we applied a hierarchy of statuses. In a further model, we observed the outcome "vocational certificate earned during VR."

To examine our research questions, we conducted multinomial logistic regression analyses for the labor market outcomes three (see Supplementary File) and five years after VR started in 2010 (see Table 2). Thus, competing outcome statuses could be observed simultaneously and were measured in reference to each other. We estimated the labor market outcomes in reference to our independent variable of interest, i.e., initial receipt of BIS in the household/role of recipient, and controlled for further characteristics. We present the results as the average marginal effects (AMEs) to ensure the comparability of results (Long \& Freese, 2014). The AME is interpreted as the difference between the likelihood of transitioning into one outcome status and the likelihood of transitioning into any other outcome status. Additionally, the outcome "vocational certificate earned during VR" was estimated using logistic regression (see Table 2). We conducted all analyses using STATA 16 with robust standard errors.

\section{Results}

\subsection{Descriptive Analyses}

Our population of YPWD beginning VR in 2010 consists of more men than women and most of them were aged between 17 and 20 (Table 1). 35\% came from households receiving BIS: $11 \%$ formed their own households and $24 \%$ lived with their parents. Fifty-seven percent achieved a lower secondary schooling certificate, $24 \%$ had no schooling certificate. Almost half of the population started VR directly after school: $25 \%$ came from special schools, $5 \%$ attended regular schools, and $17 \%$ attended vocational schools. Ten percent had an officially acknowledged severe disability or equal status; in terms of the type of disability, $68 \%$ had learning disabilities, $17 \%$ had psychological disabilities, and $14 \%$ had another type of disability.

Observing the whole VR process, we see that $50 \%$ of the YPWD participated in prevocational training programs followed by vocational training, $24 \%$ participated in prevocational training only, and $9 \%$ participated in vocational training only. Seven percent were accepted for VR but did not take part in any program. Within the 
vocational training programs, the occupational requirement level was registered. Most of the occupations were at a medium level in terms of complex specialist activities (44\%).

It was interesting to observe the differences based on the initial receipt of BIS in the household/role of recipient regarding reasons to end VR due to a lack of cooperation or a lack of prospective integration (total 32\%). Among YPWD coming from poor households, $37 \%$ of those living in their own household and $41 \%$ of those living with their parents ended VR due to a lack of cooperation or a lack of prospective integration, whereas for YPWD not receiving BIS, these reasons were reported in only $26 \%$ of cases.
With reference to the labor market outcomes five years after VR began, 23\% were employed, 18\% were unemployed and receiving BIS, $17 \%$ were still in VR, and $25 \%$ could not be found in the register. Regarding the outcome "vocational certificate earned during VR," we observed that $46 \%$ earned an occupational certificate during the VR process (Table 1).

\subsection{Multivariate Analyses}

In our multivariate results, we focus on the fifth year after VR began in 2010, as we would like to take a long-run perspective (for results in the intermediate perspective after three years see the Supplementary File; we

Table 1. Descriptive statistics of the population.

\begin{tabular}{|c|c|c|c|}
\hline \multicolumn{2}{|l|}{ Total (\%) } & \multicolumn{2}{|l|}{ Total (\%) } \\
\hline \multicolumn{2}{|l|}{$\begin{array}{l}\text { Initial receipt of BIS in the household/role of } \\
\text { recipient }\end{array}$} & \multicolumn{2}{|l|}{ Gender } \\
\hline household without BIS & 65 & female & 39 \\
\hline household with BIS & 35 & & \\
\hline ... role: own household & 11 & Type of program pattern in VR & 10 \\
\hline ... role: living with parents & 24 & $\begin{array}{l}\text { other } \\
\text { only prevocational training }\end{array}$ & 24 \\
\hline \multicolumn{2}{|l|}{$\begin{array}{l}\text { Officially acknowledged severe disability or equal } \\
\text { status }\end{array}$} & $\begin{array}{l}\text { only vocational training } \\
\text { no participation }\end{array}$ & $\begin{array}{l}9 \\
7\end{array}$ \\
\hline yes & 10 & prevocational and vocational training & 50 \\
\hline no & 90 & \multicolumn{2}{|l|}{ Occupational requirement level } \\
\hline \multicolumn{2}{|l|}{ Type of disability } & missing & 42 \\
\hline psychological disability & 17 & unskilled/semiskilled activities & 11 \\
\hline learning disability & 68 & specialist activities & 44 \\
\hline other disability & 14 & complex specialist activities & 2 \\
\hline \multicolumn{2}{|l|}{ Age group } & highly complex specialist activities & 1 \\
\hline under 17 & 26 & \multicolumn{2}{|l|}{ Reason for ending VR } \\
\hline under 17 & 55 & did not yet finish VR & 10 \\
\hline 21 to 24 & 14 & maintained employment & 5 \\
\hline 25 and older & 4 & found employment & 22 \\
\hline \multicolumn{2}{|l|}{ Schooling certificate } & transitioned to sheltered employment & 6 \\
\hline no schooling certificate & 11 & medical rehabilitation/sickness & 7 \\
\hline certificate from a special school & 13 & withdrawal of VR application & 4 \\
\hline lower secondary schooling certificate & 57 & lack of cooperation/integration perspectives & 32 \\
\hline medium secondary schooling certificate & 14 & other reasons & 15 \\
\hline higher secondary schooling certificate & 4 & Outcome variables & \\
\hline \multicolumn{2}{|l|}{ Status before VR } & \multirow{2}{*}{\multicolumn{2}{|c|}{$\begin{array}{l}\text { Status five years after the beginning of the VR } \\
\text { process }\end{array}$}} \\
\hline career counselling & 15 & & \\
\hline registered unemployed or in search for work & 22 & BIS & 18 \\
\hline employment & 5 & employed & 23 \\
\hline vocational school & 17 & sheltered workshops & 4 \\
\hline regular school & 5 & still in VR & 17 \\
\hline special school & 25 & no information & 25 \\
\hline prevocational training program & 4 & other & 14 \\
\hline \multirow[t]{2}{*}{ participation in a general ALMP } & 7 & Vocational certificate earned during VR & \\
\hline & & yes & 46 \\
\hline
\end{tabular}

Source: Own calculations based on administrative data from RehaPro. Note: $\mathrm{N}=36,645$. 
only refer to the three-year-perspective where it adds to the results). Model 1 a refers to determinants to be in one of the five alternative labor market outcomes five years after starting VR (Table 2). Persons receiving BIS after five years were more likely female, older than 20 , with low schooling level. Thus, persons without any schooling certificate and those who graduated from a special school had the highest chance of relying on BIS later. The receipt of BIS specifically depended on the type of program pattern during VR. In particular, those who took part only in prevocational training programs and not any vocational training showed a five PP higher chance of receiving BIS. We observed the strongest effect in YPWD from poor contexts. In particular, persons who were already receiving BIS at the beginning of the VR process-independent of whether they personally formed their own household (14 PPs) or lived in the parental household (11 PPs)were very likely to receive BIS three and five years after VR began in 2010.

Whether VR is generally considered successful-by financers, service providers or supported-is closely related to employment after VR. The model shows that those initially receiving BIS have lower chances to be employed. The program pattern attended during VR was an important predictor for employment. Those who participated only in vocational training programs without prior prevocational training had an eleven PP higher chance of being employed after five years than those without any program participation. Those participating in prevocational training followed by vocational training had comparably low chance of employment. This can be explained by the fact that their VR process took longer; regarding the outcome "still/again in VR," we observed that those showing this program pattern were most likely to be in VR after three (57 PPs) and five years (24 PPs). Furthermore, persons with psychological disabilities were less likely to receive employment after five years.

Programs with sheltered workshops very often lead to an automatic pathway toward sheltered employment. If YPWD conducted their occupational orientation and qualification within sheltered workshops (other program patterns), they were 34 PPs more likely to continue their employment there. Furthermore, they were less likely to take up (regular) employment but were also less likely to receive BIS according to Social Code II, as they fall under the responsibility of the Social Code XII.

(Still/again) in VR were especially those who participated in the pattern "prevocational and vocational training" reflecting the longer duration. There is no clear relationship to initial poverty in terms of BIS receipt.

Finally, the outcome category, "no information" comprises those without any information in the registered data after five years. They were more likely to be 25 or older, to not have a schooling certificate (3 PPs), and to be accepted for VR but not take part in any program. Furthermore, those were more likely to have psychological disabilities (7 PPs) and were less likely to initially receive BIS. Thus, they are persons with very low institutional attachments.

To sum up, initial poverty whether in the own or parental household is a strong predictor for receiving BIS five years after starting VR. Additionally, poor YPWD have a decreased likelihood for employment.

Model 2 shows the likelihood for earning a vocational certificate during VR. We found that the higher the schooling certificate was, the higher the chance of earning a vocational certificate. Relatedly, those aspiring to achieve an occupational requirement level of "complex specialist" or "specialist" showed the strongest effects. But even under control of schooling certificate and the occupational requirement level, persons from households receiving BIS in their own household had a five PP lower chance of earning vocational certificates than those not receiving BIS. Persons from households receiving BIS in their parents' household had a three PP lower chance of earning vocational certificates than those not receiving BIS. Furthermore, persons with psychological disabilities had the lowest chances of earning vocational certificates, having a 5 PP lower chance than those with learning disabilities.

\section{Discussion}

In this study, we shed light on an often-overlooked population: YPWD facing the double burden of disability and poverty in their transition to the labor market. Therefore, we used large-scale representative German administrative data on YPWD starting VR in 2010 and followed their employment trajectories for five years in order to draw a holistic picture. Nevertheless, some personal characteristics, e.g., complete household information for all participants, occupational limitations, and subjective ratings, e.g., of health, were missing.

Our results show that there is a large difference in employment chances between poor and non-poor YPWD after VR: Poor YPWD less often take up vocational training opportunities and employment and are more often in poverty contexts after five years. Related to this, they end VR more often due to a lack of cooperation with VR personnel at public employment agencies, case managers at job centers, and educational service providers. Therefore, poor YPWD do not seem to profit from VR in the same way as other YPWD. Thus, disability-specific programs should be more tailored to the comprehensive social situations of participants, and counsellors should be more sensitive to their social backgrounds. In addition to previous findings (Tophoven et al., 2019), we find that young people with psychological disabilities in VR have the lowest chance of earning vocational certificates in the context of VR, which might be a reason for their low employment chances despite higher initial qualifications.

The current support system seems to fulfill the complex needs of poor young people and those with psychological disabilities to a lesser extent than those of 
Table 2. Results of the multivariate analyses.

\begin{tabular}{|c|c|c|c|c|c|c|}
\hline & \multicolumn{5}{|c|}{$\begin{array}{l}\text { Model 1a: Multinomial logistic regression: Labor market } \\
\text { outcomes five years after VR began in } 2010\end{array}$} & \multirow{2}{*}{$\begin{array}{l}\text { Model 2: Logistic } \\
\text { regression: } \\
\text { Vocational certificate } \\
\text { earned during VR }\end{array}$} \\
\hline & BIS & Employment & $\begin{array}{l}\text { Sheltered } \\
\text { employment }\end{array}$ & $\begin{array}{l}\text { (Still/again) } \\
\text { in VR }\end{array}$ & No information & \\
\hline \multicolumn{7}{|c|}{ Initial receipt of BIS in the household/role of recipient (ref.: no receipt) } \\
\hline in own household & $\begin{array}{l}0.14^{* * *} \\
(0.01)\end{array}$ & $\begin{array}{l}-0.04^{* * *} \\
(0.01)\end{array}$ & $\begin{array}{l}-0.01 * * * \\
(0.00)\end{array}$ & $\begin{array}{l}-0.02^{*} \\
(0.01)\end{array}$ & $\begin{array}{l}-0.03 * * \\
(0.01)\end{array}$ & $\begin{array}{l}-0.05^{* * *} \\
(0.01)\end{array}$ \\
\hline living with parents & $\begin{array}{l}0.11^{* * *} \\
(0.00)\end{array}$ & $\begin{array}{l}-0.04 * * * \\
(0.00)\end{array}$ & $\begin{array}{l}-0.01 * * * \\
(0.00)\end{array}$ & $\begin{array}{l}0.01^{* *} \\
(0.00)\end{array}$ & $\begin{array}{l}-0.03 * * * \\
(0.01)\end{array}$ & $\begin{array}{l}-0.03^{* * *} \\
(0.01)\end{array}$ \\
\hline \multicolumn{7}{|c|}{ Gender (ref.: female) } \\
\hline male & $\begin{array}{l}-0.06 * * * \\
(0.00)\end{array}$ & $\begin{array}{l}0.06^{* * *} \\
(0.00)\end{array}$ & $\begin{array}{l}0 \\
(0.00)\end{array}$ & $\begin{array}{c}0.01 \\
(0.00)\end{array}$ & $\begin{array}{l}-0.01 * \\
(0.00)\end{array}$ & $\begin{array}{l}0.01^{* *} \\
(0.00)\end{array}$ \\
\hline \multicolumn{7}{|c|}{ Age group (ref.: 17 to 20 ) } \\
\hline under 17 & $\begin{array}{l}-0.04 * * * \\
(0.00)\end{array}$ & $\begin{array}{l}-0.01^{* *} \\
(0.00)\end{array}$ & $\begin{array}{l}0 \\
(0.00)\end{array}$ & $\begin{array}{l}0.04 * * * \\
(0.00)\end{array}$ & $\begin{array}{l}0 \\
(0.01)\end{array}$ & $\begin{array}{c}0.01 \\
(0.01)\end{array}$ \\
\hline 21 to 24 & $\begin{array}{l}0.07^{* * *} \\
(0.01)\end{array}$ & $\begin{array}{l}0.02^{* *} \\
(0.01)\end{array}$ & $\begin{array}{l}0^{*} \\
(0.00)\end{array}$ & $\begin{array}{l}-0.06^{* * *} \\
(0.01)\end{array}$ & $\begin{array}{c}0.01 \\
(0.01)\end{array}$ & $\begin{array}{c}0.01 * \\
(0.01)\end{array}$ \\
\hline 25 and older & $\begin{array}{l}0.07^{* * *} \\
(0.01)\end{array}$ & $\begin{array}{l}0 \\
(0.01)\end{array}$ & $\begin{array}{l}0 \\
(0.00)\end{array}$ & $\begin{array}{l}-0.07^{* * *} \\
(0.01)\end{array}$ & $\begin{array}{l}0.04 * * \\
(0.01)\end{array}$ & $\begin{array}{l}-0.02 \\
(0.01)\end{array}$ \\
\hline \multicolumn{7}{|c|}{ Schooling certificate (ref.: graduation from special school) } \\
\hline no & $\begin{array}{l}0.03^{* * *} \\
(0.01)\end{array}$ & $\begin{array}{c}0.01 \\
(0.01)\end{array}$ & $\begin{array}{l}-0.01 * * * \\
(0.00)\end{array}$ & $\begin{array}{l}-0.06^{* * *} \\
(0.01)\end{array}$ & $\begin{array}{l}0.03^{* *} \\
(0.01)\end{array}$ & $\begin{array}{l}-0.06 * * * \\
(0.01)\end{array}$ \\
\hline $\begin{array}{l}\text { lower secondary } \\
\text { school certificate }\end{array}$ & $\begin{array}{l}-0.03 * * * \\
(0.01)\end{array}$ & $\begin{array}{l}0.03^{* * *} \\
(0.01)\end{array}$ & $\begin{array}{l}-0.01 * * * \\
(0.00)\end{array}$ & $\begin{array}{c}0.01 \\
(0.01)\end{array}$ & $\begin{array}{c}-0.01+ \\
(0.01)\end{array}$ & $\begin{array}{l}0.1^{* * *} \\
(0.01)\end{array}$ \\
\hline $\begin{array}{l}\text { higher secondary } \\
\text { school certificate }\end{array}$ & $\begin{array}{l}-0.07^{* * *} \\
(0.01)\end{array}$ & $\begin{array}{l}0.04^{* * *} \\
(0.01)\end{array}$ & $\begin{array}{l}-0.02 * * * \\
(0.00)\end{array}$ & $\begin{array}{l}0.05^{* * *} \\
(0.01)\end{array}$ & $\begin{array}{l}-0.03^{* * *} \\
(0.01)\end{array}$ & $\begin{array}{l}0.18^{* * *} \\
(0.01)\end{array}$ \\
\hline $\begin{array}{l}\text { university entrance } \\
\text { qualification }\end{array}$ & $\begin{array}{l}-0.08^{* * *} \\
(0.01)\end{array}$ & $\begin{array}{l}0.04^{* *} \\
(0.01)\end{array}$ & $\begin{array}{l}-0.02 * * * \\
(0.00)\end{array}$ & $\begin{array}{c}0.01 \\
(0.01)\end{array}$ & $\begin{array}{l}-0.03^{* *} \\
(0.01)\end{array}$ & $\begin{array}{l}0.25^{* * *} \\
(0.01)\end{array}$ \\
\hline \multicolumn{7}{|c|}{ Disability status (ref.: no) } \\
\hline severely disabled & $\begin{array}{c}-0.02+ \\
(0.01)\end{array}$ & $\begin{array}{l}-0.01 \\
(0.01)\end{array}$ & $\begin{array}{l}0 \\
(0.00)\end{array}$ & $\begin{array}{l}0.03^{* * *} \\
(0.01)\end{array}$ & $\begin{array}{c}0.02 * \\
(0.01)\end{array}$ & $\begin{array}{c}-0.01+ \\
(0.01)\end{array}$ \\
\hline \multicolumn{7}{|c|}{ Type of program pattern in VR (ref.: no participation) } \\
\hline other & $\begin{array}{l}-0.12^{* * *} \\
(0.01)\end{array}$ & $\begin{array}{l}-0.18^{* * *} \\
(0.01)\end{array}$ & $\begin{array}{l}0.34^{* * *} \\
(0.01)\end{array}$ & $\begin{array}{l}0.18^{* * *} \\
(0.01)\end{array}$ & $\begin{array}{l}-0.11^{* * *} \\
(0.01)\end{array}$ & $\begin{array}{l}-0.14^{* * *} \\
(0.01)\end{array}$ \\
\hline $\begin{array}{l}\text { only prevocational } \\
\text { training }\end{array}$ & $\begin{array}{l}0.05^{* * *} \\
(0.01)\end{array}$ & $\begin{array}{l}-0.04^{* * *} \\
(0.01)\end{array}$ & $\begin{array}{l}0 \\
(0.00)\end{array}$ & $\begin{array}{l}0.02^{* * *} \\
(0.00)\end{array}$ & $\begin{array}{l}-0.04^{* * *} \\
(0.01)\end{array}$ & $\begin{array}{l}-0.09 * * * \\
(0.01)\end{array}$ \\
\hline $\begin{array}{l}\text { only vocational } \\
\text { training }\end{array}$ & $\begin{array}{l}-0.04 * * * \\
(0.01)\end{array}$ & $\begin{array}{l}0.11^{* * *} \\
(0.01)\end{array}$ & $\begin{array}{l}0 \\
(0.00)\end{array}$ & $\begin{array}{l}0.07^{* * *} \\
(0.00)\end{array}$ & $\begin{array}{l}-0.12 * * * \\
(0.01)\end{array}$ & $\begin{array}{l}0.22 * * * \\
(0.01)\end{array}$ \\
\hline $\begin{array}{l}\text { prevocational \& } \\
\text { vocational training }\end{array}$ & $\begin{array}{l}0 \\
(0.01)\end{array}$ & $\begin{array}{l}-0.04^{* * *} \\
(0.01)\end{array}$ & $\begin{array}{l}0+ \\
(0.00)\end{array}$ & $\begin{array}{l}0.24^{* * *} \\
(0.00)\end{array}$ & $\begin{array}{l}-0.17^{* * *} \\
(0.01)\end{array}$ & $\begin{array}{l}0.21^{* * *} \\
(0.01)\end{array}$ \\
\hline \multicolumn{7}{|c|}{ Type of main disability (ref.: learning) } \\
\hline psychological & $\begin{array}{l}-0.01 \\
(0.01)\end{array}$ & $\begin{array}{l}-0.09 * * * \\
(0.01)\end{array}$ & $\begin{array}{l}0 \\
(0.00)\end{array}$ & $\begin{array}{l}0.03^{* * *} \\
(0.01)\end{array}$ & $\begin{array}{l}0.07^{* * *} \\
(0.01)\end{array}$ & $\begin{array}{l}-0.05^{* * *} \\
(0.01)\end{array}$ \\
\hline other & $\begin{array}{l}-0.04 * * * \\
(0.01)\end{array}$ & $\begin{array}{l}-0.03 * * * \\
(0.01)\end{array}$ & $\begin{array}{l}0.01 * * * \\
(0.00)\end{array}$ & $\begin{array}{l}0.05 * * * \\
(0.01)\end{array}$ & $\begin{array}{l}0.03 * * * \\
(0.01)\end{array}$ & $\begin{array}{l}0.02 * * * \\
(0.01)\end{array}$ \\
\hline
\end{tabular}


Table 2. (Cont.) Results of the multivariate analyses.

\begin{tabular}{|c|c|c|c|c|c|c|}
\hline & \multicolumn{5}{|c|}{$\begin{array}{l}\text { Model 1a: Multinomial logistic regression: Labor market } \\
\text { outcomes five years after VR began in } 2010\end{array}$} & \multirow{2}{*}{$\begin{array}{l}\text { Model 2: Logistic } \\
\text { regression: } \\
\text { Vocational certificate } \\
\text { earned during VR }\end{array}$} \\
\hline & BIS & Employment & $\begin{array}{l}\text { Sheltered } \\
\text { employment }\end{array}$ & $\begin{array}{l}\text { (Still/again) } \\
\text { in VR }\end{array}$ & No information & \\
\hline \multicolumn{7}{|c|}{ Requirement level of occupation (ref.: unskilled or semiskilled) } \\
\hline no information & $\begin{array}{l}0.08^{* * *} \\
(0.01)\end{array}$ & $\begin{array}{l}-0.17^{* * *} \\
(0.01)\end{array}$ & $\begin{array}{l}0 \\
(0.00)\end{array}$ & $\begin{array}{l}-0.11 * * * \\
(0.01)\end{array}$ & $\begin{array}{l}0.18^{* * *} \\
(0.01)\end{array}$ & $\begin{array}{l}-0.17^{* * *} \\
(0.01)\end{array}$ \\
\hline specialist & $\begin{array}{l}-0.02 * * * \\
(0.01)\end{array}$ & $\begin{array}{c}0.01 \\
(0.01)\end{array}$ & $\begin{array}{l}-0.01^{* * *} \\
(0.00)\end{array}$ & $\begin{array}{c}0.01 * \\
(0.01)\end{array}$ & $\begin{array}{c}0.01 \\
(0.01)\end{array}$ & $\begin{array}{l}0.12^{* * *} \\
(0.01)\end{array}$ \\
\hline complex specialist & $\begin{array}{l}-0.05^{* * *} \\
(0.01)\end{array}$ & $\begin{array}{c}0.01 \\
(0.02)\end{array}$ & $\begin{array}{c}-0.03^{* *} \\
(0.01)\end{array}$ & $\begin{array}{l}0.07^{* * * *} \\
(0.02)\end{array}$ & $\begin{array}{l}0 \\
(0.02)\end{array}$ & $\begin{array}{l}0.16^{* * * *} \\
(0.02)\end{array}$ \\
\hline highly complex & $\begin{array}{c}-0.03+ \\
(0.02)\end{array}$ & $\begin{array}{l}0 \\
(0.02)\end{array}$ & $\begin{array}{l}-0.01 \\
(0.01)\end{array}$ & $\begin{array}{l}-0.02 \\
(0.02)\end{array}$ & $\begin{array}{l}0.07 * * * \\
(0.02)\end{array}$ & $\begin{array}{c}0.05^{*} \\
(0.02)\end{array}$ \\
\hline Observations & 36,557 & & & & & 36,557 \\
\hline Pseudo $R^{2}$ & 0.1887 & & & & & 0.2752 \\
\hline
\end{tabular}

Source: Own calculations based on administrative data from RehaPro. Notes: AMEs, standard errors are in parentheses: ${ }^{*} p<0.05$, $* * p<0.01, * * * p<0.001$; the category "other statuses" is not displayed.

other YPWD. Thus, our findings are in line with those of Pisoni (2018), as some of the young people most in need of support are unable to benefit from social policy programs, reflecting a Matthew effect within the target group. Therefore, the state support system must also be researched in more detail to provide suitable individual holistic support approaches. For example, findings from Sweden regarding youth with complex needs identify central barriers within the system of specialized support services to be fragmented support and a lack of continuity (Almqvist \& Lassinantti, 2018). Furthermore, our study shows, as already addressed by other studies (Schreiner, 2018), the overwhelming path dependency into sheltered workshops away from the first labor market for some individuals, and this seems to be independent of the type of disability. Given the demand for inclusion, it is necessary to consider the extent to which German transition systems need to be changed and how institutional support systems can be established to accompany people with different needs throughout their lives (Rosenberger, 2017).

\section{Conclusion}

Although poor YPWD find their way to VR, our study shows that many of them end VR due to a lack of cooperation and a large portion do not seem to find their way into vocational training and employment but rather continue to receive welfare benefits over a very long period. We conclude that poverty and disability support should not be examined separately, as they are interrelated. In addition, we need a more holistic perspective on disability and the individual needs and rights of those in VR (Shakespeare et al., 2018), particularly regarding support systems. Future research should focus on the exact barriers that YPWD from poor households face and how these young people can be reached more appropriately in the context of VR counseling. Through qualitative research, YPWD, VR counsellors at public employment agencies, case managers at job centers, and experts at educational service providers should be questioned about these barriers to find solutions to these interrelated challenges. Regarding the STWT of YPWD and young people in disadvantaged situations in general, we need to look even more closely at the actual inclusiveness of the German school and vocational education system including the VR process. This is not limited to YPWD. Further reforms should aim at the inclusion of all young people and their individual needs, and give them labor market perspectives.

\section{Acknowledgments}

We thank two anonymous reviewers and the editors for their helpful comments.

\section{Conflict of Interests}

The authors declare no conflict of interests.

\section{Supplementary Material}

Supplementary material for this article is available online in the format provided by the author (unedited).

\section{References}

Achatz, J., Jahn, K., \& Schels, B. (2020). On the nonstandard routes: Vocational training measures in the school-to-work transitions of lower-qualified youth 
in Germany. Journal of Vocational Education \& Training. Advance online publication. https://doi.org/ 10.1080/13636820.2020.1760335

Almqvist, A.-L., \& Lassinantti, K. (2018). Young people with complex needs meet complex organizations: An interview study with Swedish professionals about sustainable work practices. Community, Work \& Family, 21(5), 620-635. https://doi.org/10.1080/ 13668803.2018 .1527758

Bäcker, G., Naegele, G., \& Bispinck, R. (2020). Sozialpolitik und soziale Lage [Social policy and social conditions]. In G. Bäcker, G. Naegele, \& R. Bispinck (Eds.), Sozialpolitik und soziale Lage in Deutschland: Ein Handbuch [Social policy and social conditions in Germany: A handbook] (pp. 1-54). Wiesbaden: Springer. https://doi.org/10.1007/978-3-658-06249-1_1

Becker, R., \& Lauterbach, W. (2016). Bildung als PrivilegUrsachen, Mechanismen, Prozesse und Wirkungen. [Education as a privilege: Causes, mechanisms, processes and effects]. In R. Becker \& W. Lauterbach (Eds.), Bildung als Privileg: Erklärungen und Befunde zu den Ursachen der Bildungsungleichheit [Education as a privilege: Explanations and findings on the causes of educational inequality] (pp. 3-53). Springer. https://doi.org/10.1007/978-3-65811952-2_1

Blanck, J. M., Edelstein, B., \& Powell, J. J. W. (2013). Persistente schulische Segregation oder Wandel zur inklusiven Bildung? Die Bedeutung der UNBehindertenrechtskonvention für Reformprozesse in den deutschen Bundesländern [Persistent school segregation or change towards inclusive education? The Significance of the UN Convention on the Rights of Persons with Disabilities for Reform Processes in the German Federal States] Schweizerische Zeitschrift für Soziologie = Revue Suisse de Sociologie, 39(5), 267-292.

Blossfeld, H.-P. (1988). Sensible Phasen im Bildungsverlauf. Eine Längsschnittanalyse über die Prägung von Bildungskarrieren durch den gesellschaftlichen Wandel [Sensitive stages in educational careers. A longitudinal study on the influence of societal changes on educational careers]. Zeitschrift für Pädagogik, 34(1), 45-63.

Boeckh, J., Huster, E.-U., Benz, B., \& Schütte, J. D. (2017). Sozialpolitik in Deutschland: Eine systematische Einführung [Social policy in Germany: A systematic introduction]. Springer. https://doi.org/10.1007/ 978-3-658-13695-6

Brooks-Gunn, J., \& Duncan, G. J. (1997). The effects of poverty on children. The Future of Children, 7(2), 55-71. https://doi.org/10.2307/1602387

Enayati, H., \& Karpur, A. (2018). Impact of participation in school-to-work programs on postsecondary outcomes for youth with disabilities from low-income families. Journal of Disability Policy Studies, 29(4), 235-244. https://doi.org/10.1177\% 2F1044207318789419
Federal Ministry of Labour and Social Affairs. (Eds.). (2020). Social security at a glance 2020.

Federal Ministry of Labour and Social Affairs. (Eds.). (2021). Dritter Teilhabebericht der Bundesregierung über die Lebenslagen von Menschen mit Beeinträchtigungen [Third report of the German Federal Government on the living conditions of people with disabilities].

Gebhardt, M., Tretter, T., Schwab, S., \& GasteigerKlicpera, B. (2011). The transition from school to the workplace for students with learning disabilities: Status quo and the efficiency of pre-vocational and vocational training schemes. European Journal of Special Needs Education, 26(4), 443-459. https://doi.org/ $10.1080 / 08856257.2011 .597181$

Groh-Samberg, O., \& Voges, W. (2014). Precursors and consequences of youth poverty in Germany. Longitudinal and Life Course Studies, 5(2), 151-172. https:// doi.org/10.14301/llcs.v5i2.281

Heimlich, U. (2017). Zwischen Inklusion und Exklusion [Between inclusion and exclusion]. In M. Gercke, S. Opalinski, \& T. Thonagel (Eds.), Inklusive Bildung und gesellschaftliche Exklusion: ZusammenhängeWidersprüche-Konsequenzen [Inclusive education and social exclusion: Connections-contradictionsconsequences] (pp. 87-98). Springer. https://doi. org/10.1007/978-3-658-17084-4_6

Klemm, K. (2021). Inklusion in Deutschlands Schulen. Entwicklungen-Erfahrungen-Erwartungen [Inclusion in German schools. Developmentsexperiences-expectations]. Beltz Verlagsgruppe.

KMK. (2011). Beschluss der Kultusministerkonferenz (KMK). Inklusive Bildung von Kindern und Jugendlichen mit Behinderungen in Schulen [Resolution of the Standing Conference of the Ministers of Education and Cultural Affairs. Inclusive education of children and youth with disabilities in schools].

KMK. (2020). Statistische Veröffentlichungen der Kultusministerkonferenz (KMK). Sonderpädagogische Förderung in Schulen 2009 bis 2018 [Statistical publications of the Standing Conference of the Ministers of Education and Cultural Affairs. Special education in schools 2009 to 2018].

Lampert, T., \& Kuntz, B. (2019). Auswirkungen von Armut auf den Gesundheitszustand und das Gesundheitsverhalten von Kindern und Jugendlichen [Effects of poverty for health and health behavior of children and adolescents]. BundesgesundheitsblattGesundheitsforschung-Gesundheitsschutz, 62(10), 1263-1274. https://doi.org/10.1007/s00103-01903009-6

Long, J. S., \& Freese, J. (2014). Regression models for categorical dependent variables using Stata (3rd ed.). Stata Press.

Marshall, V. W., \& Mueller, M. M. (2003). Theoretical roots of the life-course perspective. In W. R. Heinz \& V. W. Marshall (Eds.), Social dynamics of the life course: Transitions, institutions, and interrelations 
(pp. 3-32). De Gruyter.

Munz-König, E. (2013). Armutsgefährdungsquote und Mindestsicherungsquote: Zwei Indikatoren zur Messung monetärer Armut [The 'at risk of poverty' rate and the rate of recipients of minimum social security benefits: Two indicators to measure monetary poverty]. Sozialer Fortschritt, 62(5), 123-132. https://doi.org/10.3790/sfo.62.5.123

Niehaus, M., Kaul, T., Friedrich-Gärtner, L., Klinkhammer, D., \& Menzel, F. (2012). Zugangswege junger Menschen mit Behinderung in Ausbildung und Beruf [Ways of entering vocational training and employment for young people with disabilities]. Bundesministerium für Bildung und Forschung.

Nullmeier, F. (2018). Changes in German social policy, 1990-2018. Social Work \& Society, 16(2).

Osgood, D. W., Foster, E. M., Flanagan, C., \& Ruth, G. R. (2005). Introduction: Why focus on the transition to adulthood for vulnerable populations? In D. W. Osgood (Ed.), On your own without a net: The transition to adulthood for vulnerable populations ( $\mathrm{pp}$. 1-26). University of Chicago Press.

Paulus, W., \& Matthes, B. (2013). The German classification of occupations 2010-Structure, coding and conversion table (Report 08/2013). Research Data Centre (FDZ) of the Federal Employment Agency at the Institute for Employment Research.

Pfahl, L., \& Powell, J. J. W. (2011). Legitimating school segregation. The special education profession and the discourse of learning disability in Germany. Disability \& Society, 26(4), 449-462. https://doi.org/10.1080/ 09687599.2011 .567796

Pisoni, D. (2018). Between idealism and pragmatism: Social policies and Matthew effect in vocational education and training for disadvantaged youth in Switzerland. Social Inclusion, 6(3), 289-300. https:// doi.org/10.17645/si.v6i3.1515

Protsch, P., \& Solga, H. (2016). The social stratification of the German VET system. Journal of Education and Work, 29(6), 637-661. https://doi.org/10.1080/ 13639080.2015 .1024643

Reims, N., \& Gruber, S. (2014). Junge Rehabilitanden in der Ausbildung am Uebergang in den Arbeitsmarkt [Young rehabilitants in vocational training at the transition to the labor market]. Die Rehabilitation, 53(6), 376-383. https://doi.org/10.1055/s-0034-1370986

Reims, N., Tophoven, S., Tisch, A., Jentzsch, R., Nivorozhkin, A., Köhler, M., Rauch, A., \& Thomsen, U. (2018). Aufbau und Analyse des LTA-Rehaprozessdatenpanels [Construction and analysis of the RehaPro]. Bundesministerium für Arbeit und Soziales.

Rosenberger, H. (2017). Inklusion im Übergang von der Schule in Ausbildung und Arbeit? [Inclusion in the transition from school to vocational training and work] In M. Gercke, S. Opalinski, \& T. Thonagel (Eds.), Inklusive Bildung und gesellschaftliche Exklusion: Zusammenhänge-Widersprüche-Konsequenzen [Inclusive education and social exclusion: Connections-contradictions-consequences] (pp. 99-120). Springer.

Schmillen, A., \& Umkehrer, M. (2017). The scars of youth: Effects of early-career unemployment on future unemployment experience. International Labour Review, 156(3/4), 465-494. https://doi.org/ 10.1111/ilr.12079

Schreiner, M. (2018). A need for sheltered workshop reform? Perspectives from employees and legal trends due to the German Federal Participation Act. In G. Wansing, F. Welti, \& M. Schäfers (Eds.), The right to work for persons with disabilities (pp. 327-342). Nomos. https://doi.org/10.5771/ 9783845291673-326

Shakespeare, T., Cooper, H., Bezmez, D., \& Poland, F. (2018). Rehabilitation as a disability equality issue: A conceptual shift for disability studies? Social Inclusion, 6(1), 61-72. https://doi.org/10.17645/si.v6i1. 1175

Statistik der Bundesagentur für Arbeit. (2021a). Bedarfsgemeinschaften und deren Mitglieder-Dezember 2020 [BIS households and their membersDecember 2020].

Statistik der Bundesagentur für Arbeit. (2021b). Berufliche Rehabilitation-Januar 2021 [Vocational rehabilitation-January 2021].

Statistik der Bundesagentur für Arbeit. (2021c). Verweildauern im SGB II-Dezember 2020 [Durations of receipt of BIS-December 2020].

Tisch, A., Brötzmann, N., Heun, K., Rauch, A., Reims, N., Schlenker, K., \& Tophoven, S. (2017). Berufliche Rehabilitation aus Sicht der Teilnehmenden. Eine qualitative Befragung von Rehabilitanden und Rehabilitandinnen im Förderbereich der Bundesagentur für Arbeit [VR from the perspective of the participants. A qualitative survey of rehabilitants of the Federal Employment Agency]. Bundesministerium für Arbeit und Soziales.

Tophoven, S., Reims, N., \& Tisch, A. (2019). Vocational rehabilitation of young adults with psychological disabilities. Journal of Occupational Rehabilitation, 29(1), 150-162. https://doi.org/10.1007/ s10926-018-9773-y

Vinck, J., \& Van Lancker, W. (2019). An intersectional approach towards parental employment in families with a child with a disability: The case of Belgium. Work, Employment and Society, 34(2), 228-261. https://doi.org/10.1177/0950017019872648 


\section{About the Authors}

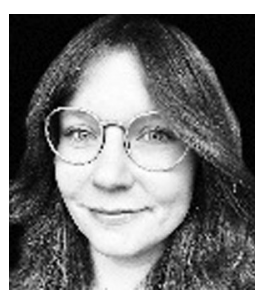

Nancy Reims (PhD in rehabilitation science) is a senior researcher at the Institute for Employment Research in Nuremberg, Germany. She works in the Joblessness and Social Inclusion Research Department. Her research focuses on transition processes of young people with disabilities from school to work in the context of vocational rehabilitation and the vocational reintegration of people with health limitations and disabilities.

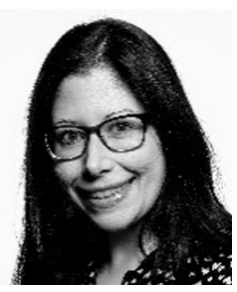

Silke Tophoven (PhD in sociology) is a professor of social policy in the Faculty of Social Sciences and Cultural Studies at the University of Applied Sciences in Duesseldorf, Germany. Her research focuses on the situation of children and adolescents in poverty as well as on vocational rehabilitation and the participation of people with support needs in the labor market. 